\title{
Governing Government-Project Owner Relationships in Water Megaprojects: a Concession Game Analysis on Allocation of Control Rights
}

\author{
Tianyu Ma ${ }^{1,2} \cdot$ Jiyong Ding ${ }^{1}$ (D) $\cdot$ Zhuofu Wang $^{1} \cdot$ Miroslaw J. Skibniewski ${ }^{2}$ \\ Received: 4 December 2019 / Accepted: 16 July 2020 / \\ Published online: 18 September 2020 \\ (C) Springer Nature B.V. 2020
}

\begin{abstract}
Studying megaprojects from the micro-foundations rooted in organizational action and interaction, this research started with an extensive literature review and therefore proposed a conceptual model for governing government-project owner relationships. A cooperative game model was further developed based on the conceptual model and concession game theory. The results showed that the relationships between government and project owner could be indeed improved by considering the allocation of control rights within a certain range $\left(0, \frac{A_{1}-A_{2}+2 B_{2}}{2 B_{1}+2 B_{2}}\right)$. Also, it was shown in two cases that project value was increased by over $10 \%$ on average when achieving the concession equilibrium, which could bring gains to both the government and project owner by redistributing the added value. This study contributes to existing research on top-level inter-organizational relationships in water megaprojects, provides important implications for maintaining cooperation between megaproject stakeholders, and suggests interesting trajectories for future research.
\end{abstract}

Keywords Water megaprojects · Project governance $\cdot$ Control rights $\cdot$ Strategic concession game

\section{Introduction}

Megaprojects are large-scale, complex ventures that are transformational and impact millions of people (Flyvbjerg 2014). The total cost spent on megaprojects annually constituted $8 \%$ of global gross domestic product (GDP) (Defense Acquisitions 2013). It is further estimated that the spending on megaprojects will increase to $24 \%$ of global GDP - or approximately USD 22 trillion per year - within the next decade, which is considered to be larger than the GDP of any

Jiyong Ding

jyding@hhu.edu.cn

1 Institute of Engineering Management, Business School, Hohai University, Nanjing, China

2 Center of Excellence in Project Management, A.J. Clark School of Engineering, University of

Maryland, College Park, MD, USA 
nation in the world (Frey 2017; Flyvbjerg and Turner 2017). Along with increased scale is therefore a constant and pressing issue in megaproject management, and never has systematic and valid knowledge about megaprojects been more important in this highly costly area of business and government (Flyvbjerg 2014).

Water megaprojects can be characterized by longer construction periods, larger regional spans, and greater environmental impact than other types of megaprojects. Most water megaprojects have costs exceeding US $\$ 1.5$ billion, and achieve the functions of agricultural irrigation, urban water supply, electric power generation, and improvement of ecological environment. The scale of water megaproject development is still accelerating now. In 2014, China proposed 172 new water megaprojects; 132 have been initiated (as of 2020) with investments exceeding US $\$ 150$ billion. In Mekong River, the water resources and hydropower projects development between countries are also rolling full steam ahead.

However, up to now the performance of many projects have been unsatisfactory: cost overruns, quality issues, progress delays, conflicts among stakeholders, corruption, and the more insidious dynamic of normalization of deviance (Pinto and Slevin, 2013; Flyvbjerg 2014; Volden and Andersen 2018). Besides the iron triangle (cost, time and scope), the performance in the organizational level have been considered more crucial to evaluate the project success in recent years. Especially, the lack of the social and environmental responsibility is strongly highlighted (Wang et al. 2017). Pinto and Slevin (2013) deduced that performance problems were the result of misaligned or underdeveloped governance mechanisms. The establishment of governance processes and rules has been considered important to ensuring that water megaprojects meet their purpose (Klakegg et al. 2008). In the case of megaprojects, managerial challenges can be best understood using project governance theory, which is the projectoriented study focusing on individuals and organizations and which has a significant correlation with project success (Joslin and Müller 2016; Danwitz 2018).

Project governance has received much attention over the last decades (Ahola et al. 2014). While the project governance framework has been well-studied, there has been little research on how to implement governance practices among key project organizations. Research into implementation best-practices deserves a more prominent role; after all, the proposal of a governance framework does not ensure that organizations will act according to the original intention (Brunet 2018). As a parallel stream of literature has argued, the correct application of project governance can improve project performance and result in project success (Van Marrewijk and Smits 2016; Badewi 2016; Derakhshan et al. 2019). What previous researchers have found is that the clarification of roles, responsibilities, and accountabilities among project participants is the key to applying project governance correctly (Müller 2009; p.2; Turner 2006; Pinto 2006). Therefore, making the relationships among water megaprojects participants clear before starting the project is helpful for the cohesiveness of the governance structure and can improve project success (Badewi 2016). However, only limited studies have focused on how to coordinate the relationships, power, and rights among key organizational units. Thus, this research aims to fill these implementation gaps and to better understand the concept of "governance-as-practice" in water megaprojects.

Governments ${ }^{1}$ are crucial stakeholders for water megaprojects, often as owner or initiator, ultimately on behalf of all citizens (Xie et al. 2017; Volden and Andersen 2018). The majority of megaprojects have a client sent by the public sector or government to represent the

\footnotetext{
${ }^{1}$ In this research, the central government, local government, and government agencies are collectively called "government".
} 
government and improve project efficiency, which implies that the client may have significant influence on the quality of project execution (Sanderson 2012; Danwitz 2018). In most countries, an administrative agency plays the role of client for these kinds of projects. This research focuses on China, where state-owned enterprises operate on the government's behalf as the water megaproject's project owner. As the responsible body, the project owner guarantees appropriate behavior by project suppliers and contactors, and is additionally responsible for project planning, fund raising, construction implementation, production and operation, debt repayment (Ministry of Water Resources 2015). However, control rights have not been distributed reasonably between government and project owner. This has caused a variety of problems, such as failures in performance appraisal, cumbersome and inefficient administrative processes, and excessive governmental intervention. The competition for control rights by intra-organizational actors will cause the organization to lose profit and efficiency (Pfeffer 1987), which fundamentally undermines the ultimate goal of governance: good governance. Therefore, an effective solution to resolving this control-rights competition, would entail controlling the game between government and project owner with a concessional attitude and a common goal of project success.

The next section presents the theoretical background including the conceptual interpretation, literature review, and study hypotheses. Section 3 describes the context of the strategic concession game and presents its application in our research question. Section 4 discusses how our findings refine the theoretical and methodological basis of water megaproject governance research. Finally, Section 5 summarizes the contributions and limitations of this study and proposes an agenda for future research.

\section{Theoretical Background}

\subsection{Conceptual Background}

\subsubsection{Project Owners of Water Megaprojects in China}

Governments in China have generally established or chosen state-owned enterprises (SOEs) for current and future water megaprojects (Chi et al. 2011; Hu et al. 2015). SOEs frequently undertake public policy objectives and can be used to improve the efficiency of public service delivery, while non-state-owned firms are considered to have strong profit-driven behaviors, which may greatly increase moral hazard and management costs (António 2017). Under this model, the entrusted SOEs are specialized entities whose sole responsibility is to work as project owners of water megaprojects. The relationships between the project owner and other participants in water megaprojects are shown in Fig. 1. This research focuses on Governance Layer 1. Generally, project owners are assigned and managed by the central government, while sometimes the central government delegates this power to local governments when the project spans several provinces.

As shown, the project owner is both a governing subject as well as a governed subject and has a crucial impact on project governance structure. The governance of such a specialpurpose vehicle has become a difficult problem for the government to address (Eweje et al. 2012; Hu et al. 2015). Generally, the Ministry of Water Resources of China (MWR) carries out professional management, while the State-owned Assets Supervision and Administration Commission of the State Council (SASAC) implements financial and behavioral supervision. 


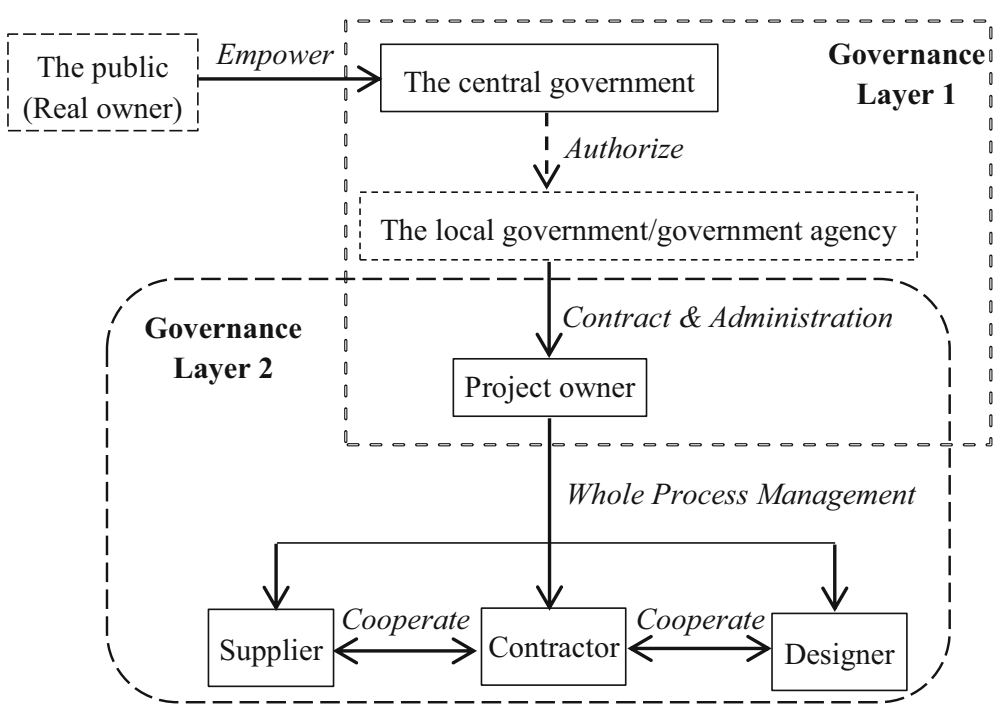

Fig. 1 Relationships between project participants

Figure 2 further dissects the relationships between project participants in Governance Layer 1. It is widely known that project governance draws from the research achievements of corporate governance (Joslin and Müller 2016). Therefore, in terms of organizational structure, this study regards a water megaproject as a company. As such, the public acts as the shareholders, the government plays the role of the board of directors, and the project owner serves as the CEO. However, while general firms usually operate in free markets, water megaprojects are a one-time event and monopolistic by nature. Moreover, project owners take on dual positions - within governmental sectors and the project governance system (Hu et al.

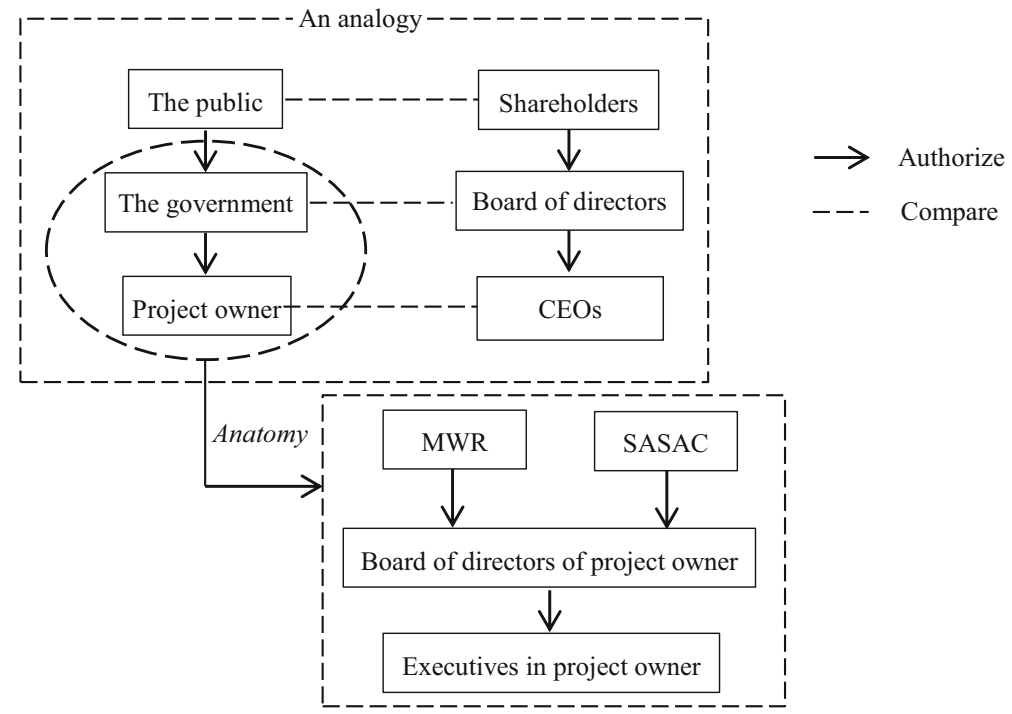

Fig. 2 Dissection of relationships between project participants in Governance Layer 1 
2015). Therefore, there is a need for enhanced academic scrutiny into this emerging organizational phenomenon.

\subsubsection{A Premise: Agent-Like Behavior or Steward-like Behavior}

Knowledge of whether a CEO has agent or steward tendencies is crucial and provides important implications for how boards monitor and incentivize CEOs. Agency theory and stewardship theory are contrasting theories about CEO behavioral intentions (Martin and Butler 2017). Under agency theory, the agent who engages in economic activities will make maximum efforts to improve their own effectiveness while the principal will bear the cost if things go poorly (Ma et al. 2018). While agency doctrine depicts top managers as individualistic, opportunistic, and self-serving, steward doctrine depicts top managers as collectivist, pro-organizational, and trustworthy (Davis et al. 1997). Agency theory implements awards and penalties to govern the agent-like behavior, while steward theory improves the cooperation between steward and principal through empowerment (Davis et al. 1997; Van Slyke 2007). Although agency theory provides valuable insights into governance and has been widely used by researchers, it has faced criticism against it and its applicability over the years (Turner and Müller 2003). An empirical study by Joslin and Müller (2016) also shows that strict control prescribed by agency doctrine does not necessarily improve the success rate of projects, while there is a significant correlation between the governance style of steward doctrine and project success.

As the project's responsible organization, the project owner in a Chinese water megaproject directly accepts the government's commission with no competition. As governmental entities, the project owner will be held under the principles and benchmarks of public service and protection, including selflessness, integrity, objectivity, honesty, explicability, openness, transparency, sense of responsibility, and justice. The main purpose of these principles and benchmarks is to build trust by influencing individual and group behavior. The performance of the project's construction and operation directly affects the promotion of the senior executives within the project owner. In practice, a project owner will work diligently on behalf of the government's interests, in view of the incentives for completing such a megaproject successfully and attaining great social and political influence. Thus, a project owner might be antagonistic towards a government's high-frequency assessments and audits, believing such measures to be due to extreme distrust. For instance, a manager who was interviewed expressed a strong dislike for monthly or even weekly assessments by government officials, considering such overly detailed assessments to be a waste of time. A common complaint among multiple companies is that the government prohibits any investment failure, which means that they must operate conservatively and will sometimes miss lucrative development opportunities. This situation tends to have a negative effect on future work, changing executives' behavior from initial steward behavior to agency behavior. Therefore, it behooves the government to think of the project owner as a dedicated steward rather than a self-serving agent, and to motivate it to maximize steward behavior for the project benefit. Therefore, a research context can be offered:

Proposition 1: The initial relationship between government and project owner is principal and steward, with the common goals of project success and societal welfare, which requires an environment of trust and cooperation. 


\subsection{Complexity of Water Megaprojects and Government - Project Owner Relationships}

What usually distinguishes a water megaproject is not the cost but the complexity (Pitsis et al. 2018). Complexity is associated with an increased number of unexpected project changes, which affects the project procurement modes and transaction costs (Tadelis 2002). Although complexity can be daunting, there is a need to "deal with complexity," to determine how organizations respond to complexity (Geraldi et al. 2011).

Governance is considered the art of addressing complexity, the goal of which is to resolve complexity in order to ensure the ordering and collective action of organizations with low cost and high efficiency (Jessop 2005; Brahm and Tarziján 2015; Sha 2017:95). In response to complexity, it holds that enterprises will adopt different organizational modes to adapt to the environment (Shenhar 2001). However, the complexity in water megaprojects is both exogenous and endogenous (Pich et al. 2002; Solak et al. 2010). In addition to environmental impacts, water megaprojects are also faced with complex problems such as the relevance of technical solutions and the incompleteness of construction knowledge (Brady and Davies 2014; Rolstadås and Schiefloe 2017). Specifically, complexity in water megaprojects is embodied in structural complexity and cognitive complexity, including complex engineering schemes, limited awareness of innovative technology and objectives, strong uncertainty from the external environment, and the participation of numerous stakeholders (Mai et al. 2018). Moreover, since there are high levels of risk and ambiguity, water megaprojects introduce a lot of complexities, which affect the organizational characteristics and the design of project governance structure. Therefore, it is important to study governance mechanisms to create a detailed solution landscape for the myriad complexities faced by such vast and costly undertakings (Caniëls et al. 2012; Peng et al. 2014; Brunet and Aubry 2018).

Project complexity is further aggravated when located in the relationship between government and project owner. In China's water megaprojects, relational complexities are characterized by the competing demands of principal-agent and bureaucratic relationships. This complex coexistence leads to excessive intervention from government and excessive political dependence by the project owner. Meanwhile the advantage of a bureaucratic relationship is being better able to manage unexpected changes than market-contract relationships (Brahm and Tarziján 2015). In addition, the effect of this complex coexistence on the control rights allocation is even more unusual. The government as project investor has strong control over the procurement, implementation, construction, management, and operation of projects, but as the actual operator and manager, the project owner does not in practice hold substantial control rights. The project owner believes it should hold more control rights to manage projects in order to guarantee competitiveness in the marketplace, while the government considers itself to have absolute control over the whole project to prevent moral hazard behaviors by the project owner. Therefore, there are divergences between the two top-level participants, creating problems falling within the scope of project governance theory. Accordingly, this study offers:

Proposition 2: Through some governing methods, project governance theory can help to resolve the complexity existing in the relationships between government and project owner. 


\subsection{Control Rights Allocation between Government and Project Owner}

Control rights are the core of the power system and governance system. They have a great impact on performance and have been regarded as an important incentive factor (Shirley and Walsh 2000). The misallocation of control rights will create negative incentives such as free cash flow agency and entrenchment effects (Shleifer and Vishny 1989). The allocation of control rights in projects has been overlooked for a long time but has recently attracted wide attention and resulted in notable achievements in Public-Private Partnership (PPP) projects. Francesconi and Muthoo (2006) applied the joint-control method to PPP projects, and proposed the idea that shared authority is optimal. While the government and PPP private partners have external relationships, the relationships between government and project owners are internalized. In a sense, the project owners are an extension of the government's functional departments.

Retrospectively, the analogy made in Section 2.1.1 is that the government plays the role of the board of directors, and the project owner serves as the CEO. Accordingly, the issue of project control rights (including proposal, approval, implementation and supervision) between government and project owner has become clearer under this context. In practice, the government delegates major operation decision-making control rights to the project owner, but retains final decision-making rights on major issues such as mergers, acquisitions, asset disposal and executive appointments (Fan et al. 2007). On the other hand, resource-based theory proposes that the control rights should be held by the knowledge owner, and advocates that the core resource owner should have the greatest decision-making power (Hoskisson et al. 2018). Furthermore, although the project owner has only mediocre control rights, it has extremely high psychological ownership (Pierce et al. 2003). Thus, the project owner may not feel trusted and may show resistance to government intervention. Long-term unbalanced trust will most likely lead to steward fatigue, which has a negative impact on projects. Project governance can use structures of authority to allocate resources and coordinate activity in projects (Pinto 2006). Using trust-based cooperation to improve the power structure, project governance can arouse the collective responsibility and intrinsic motivation of stewards (Hernandez 2012). Therefore, this study predicts:

Proposition 3: As an important governing method, control rights allocation can continually improve the cooperative relationship between government and project owner.

The conceptual model, as it derives from the above literature review, is shown in Fig. 3.

\section{Methodology}

\subsection{Parameters and Rules of Concession Game Model}

Game theory provides a framework for promoting cooperation and avoiding the waste of resources within organizations (JØrgensen and Yeung 1999; Zhi et al. 2018). Overall, the inconsistency of players' intentions leads to bargaining between players, which results in time and negotiation costs, and ultimately increases the transaction costs. Moreover, the lack of cooperation leads to an indefinite bargaining game, and results in more serious conflicts and contradictions. The aim of concession game theory is to form an effective 


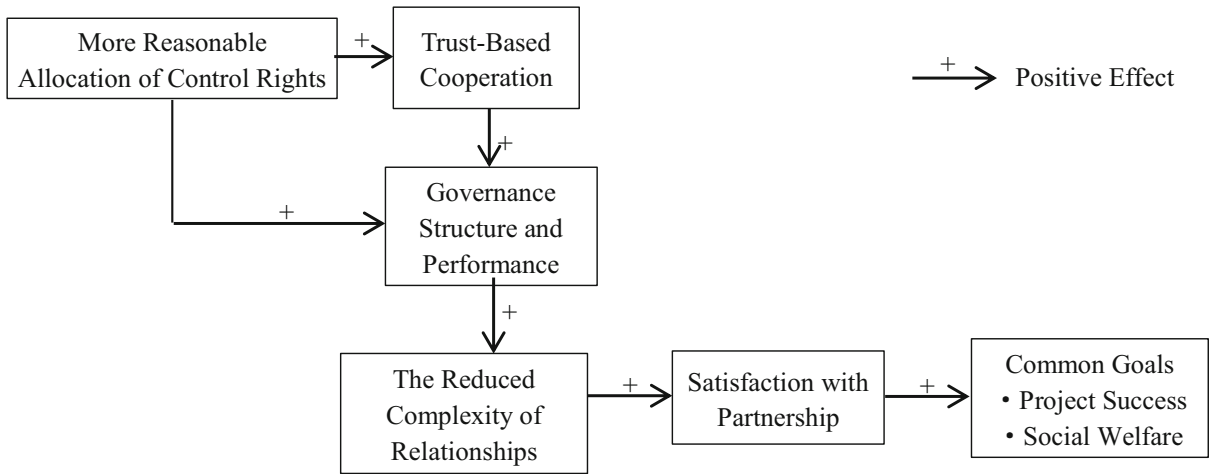

Fig. 3 Conceptual model for governance of government-project owner relationships

and widely accepted cooperative mechanism to break the deadlock. According to JØrgensen and Yeung (1999), a concession game model considers a two-player and two-stage game and seeks out a starting point which is a non-cooperative and inefficient Nash Equilibrium (NE) due to competition between the two players. The initial NE of player $i$ and player $j$ are characterized as,

$$
\begin{aligned}
& x_{i}^{N}=\operatorname{argmax}\left\{u_{i}\left(x_{i}, x_{j}^{N}\right) \mid x_{i} \in X_{i}\right\} \\
& x_{j}^{N}=\operatorname{argmax}\left\{u_{j}\left(x_{i}^{N}, x_{j}\right) \mid x_{j} \in X_{j}\right\}
\end{aligned}
$$

Among them, $u_{i}$ is the payoff of player $i$, which is strictly concave in $x_{i}$. And $x_{i}$ is the strategic action of player $i$ and belongs to its strategy space $X_{i}$, which is compact and convex. Likewise for player $j$.

In a concession game model, the assumption is that the payoffs for both players would improve if both players choose lower values for their individual actions (JØrgensen and Yeung 1999). Therefore, in seeking out greater returns than their initial NE point, the two players make concessions in their actions. In the first stage, each player negotiates for the concessions of the second stage. In the second stage, each player makes concessions based on the negotiation results. According to the concessions made by the dominant player, the follower adopts strategies to optimize his/her own benefits.

Let $S_{j} \in\left[0, x_{j}^{N}\right], j \in\{1,2\}$ and denote player $j$ 's reduction of his NE action as $x_{j}^{N}$, namely, the player $j$ 's concession. And for every unit of concession player $j$ make, player $i$ shall concede $\alpha_{i}$ times. Therefore, for $\alpha_{i} \in R^{+}, i \in\{1,2\}$ and $i \neq j$,

$$
S_{i}= \begin{cases}\alpha_{i} S_{j}, & \alpha_{i} S_{j} \leq x_{i}^{N} \\ x_{i}^{N}, & \alpha_{i} S_{j} \geq x_{i}^{N}\end{cases}
$$

And the rules of the game are as followed.

Rule1. The player who offers the more attractive $\alpha_{i} \in R^{+}, i \in\{1,2\}$ in the first stage will be the winner. Suppose player $i$ becomes the winner, then player $j$ must accept the winning $\alpha_{i}$ and has no choose but makes his concession $S_{j}$ under the winning $\alpha_{i}$. Player $i$ makes his concession according to formula 1.

Rule2. Player i's bidding $\alpha_{i}$ is more attractive and player $i$ will be the winner if 


$$
\frac{\frac{\alpha_{i} S_{j}}{x_{i}^{N}}}{\frac{S_{j}}{x_{j}^{N}}}>\frac{\frac{\alpha_{j} S_{i}}{x_{j}^{N}}}{\frac{S_{i}}{x_{i}^{N}}} \Leftrightarrow \alpha_{i} \frac{x_{j}^{N}}{x_{i}^{N}}>\alpha_{j} \frac{x_{i}^{N}}{x_{j}^{N}} \Leftrightarrow \alpha_{i}>\alpha_{j} \frac{\left(x_{i}^{N}\right)^{2}}{\left(x_{j}^{N}\right)^{2}}
$$

Conversely, player j's $\alpha_{j}$ is more attractive and player $j$ will be the winner.

In fact, there is a third case in Rule 2, that is, the formulas at both ends of Formula (2) are equal. Therefore, it is necessary to set up another rule to determine who will be the winner. Let $U_{j}^{L}$ denote player $j$ 's maximizing utility respond to a winning $\alpha_{i}$.

$$
U_{j}^{L}=U_{j}\left(x_{i}^{N}-\alpha_{i} S_{j}, x_{i}^{N}-S_{j}\right)
$$

Since player $j$ 's concession is based on $\alpha_{i}$, it can be obtained that $S_{j}=s_{j}\left(\alpha_{i}\right)$. Thus,

$$
\begin{aligned}
& U_{j}^{L}=U_{j}\left(x_{i}^{N}-\alpha_{i} s_{j}\left(\alpha_{i}\right), x_{i}^{N}-s_{j}\left(\alpha_{i}\right)\right) \\
& U_{i}^{W}=U_{i}\left(x_{i}^{N}-\alpha_{i} s_{j}\left(\alpha_{i}\right), x_{i}^{N}-s_{j}\left(\alpha_{i}\right)\right)
\end{aligned}
$$

Rule3. In the case that the bidding of two players is equally attractive, that is $\alpha_{i} \frac{x_{j}^{N}}{x_{i}^{N}}>\alpha_{j} \frac{x_{i}^{N}}{x_{j}^{N}}$, the winner is determined by who can bring greater overall utility. Play $i$ will be the winner if the following condition is satisfied.

$$
\left\{U_{i}^{W}\left(\alpha_{i}\right), U_{j}^{L}\left(\alpha_{i}\right)\right\} \geq\left\{U_{i}^{L}\left(\alpha_{i}\right), U_{j}^{W}\left(\alpha_{i}\right)\right\}
$$

Player $i$ is likely to bid too low in order to win, thus Rule 4 is to avoid an underbidding. In this case, player $j$ can replace player $i$ as the winner through the second stage's bidding.

Rule4. If player $i$ wins with an irrational $\alpha_{i}$ which satisfies

$$
U_{i}^{W}\left(\alpha_{i}\right)<U_{i}^{L}\left(\alpha_{i}\left(\frac{x_{j}^{N}}{x_{i}^{N}}\right)^{2}\right)
$$

Then player $j$ can replace player $i$ to be the winner with a winning offer $\alpha_{j}^{R}$ which satisfies

$$
U_{i}^{W}\left(\alpha_{j}^{R}\left(\frac{x_{j}^{N}}{x_{i}^{N}}\right)^{2}\right) \leq U_{i}^{L}\left(\alpha_{j}^{R}\right)
$$

Moreover, in order to achieve greater utility players, Rule 5 is also needed to avoid both sides bidding too low. The following numbers are defined to motivate Rule 5.

$$
\begin{gathered}
\alpha_{i}^{0}=\max \left\{\alpha_{i} \in R^{+} \mid U_{i}^{W}\left(\alpha_{i}\right)=\mathrm{U}_{\mathrm{i}}^{\mathrm{L}}\left(\alpha_{i}\left(\frac{x_{j}^{N}}{x_{i}^{N}}\right)^{2}\right)\right\} \\
\alpha_{i}^{m}=\underset{\alpha_{i} \geq \alpha_{i}^{o}}{\operatorname{argmax}}\left\{U_{i}^{W}\left(\alpha_{i}\right)\right\}
\end{gathered}
$$


Rule5. In the case that player $i$ loses the game with an bidding $\alpha_{i}^{s}$ and with $\alpha_{i}^{0}<\alpha_{i}^{m}$, player $j$ can be the winner with $\alpha_{j}^{P}$ which can satisfie

$$
U_{i}^{L}\left(\alpha_{j}^{P}\right) \geq \min \left\{U_{i}^{W}\left(\alpha_{i}^{S}\right), U_{i}^{L}\left(\alpha_{i}^{S}\left(\frac{x_{j}^{N}}{x_{i}^{N}}\right)^{2}\right)\right\}
$$

or let player $i$ be the winner with $\alpha_{j}^{q}$ which is satisfied

$$
U_{i}^{W}\left(\alpha_{j}^{q}\right)<U_{i}^{L}\left(\alpha_{i}^{s}\right)
$$

\subsection{Concession Game Analysis on Control Rights Allocation}

The competition of rights will make organizations perform not for profit and efficiency, which will greatly increase the transaction costs (Pfeffer 1987:27). In order to create a better cooperative environment, the government and project owner will agree with the above rules and begin a concession game. If both sides agree on the concession rules, both of them can obtain greater returns than the original Nash equilibrium. According to the JY (JØrgensen and Yeung 1999) model and the BG (Besley and Ghatak 2001) model, this research defines the original utility functions of the project, the government, the project owner are $Y_{1}, Y_{2}$, and $Y$.

$$
\begin{gathered}
Y_{1}^{0}=A_{1} x_{1}^{0}-B_{1}\left(x_{1}^{0}\right)^{2} \\
Y_{2}^{0}=A_{2} x_{2}^{0}-B_{2}\left(x_{2}^{0}\right)^{2} \\
Y^{0}=Y_{1}^{0}+Y_{2}^{0}=A_{1} x_{1}^{0}-B_{1}\left(x_{1}^{0}\right)^{2}+A_{2} x_{2}^{0}-B_{2}\left(x_{2}^{0}\right)^{2}
\end{gathered}
$$

Among them, the variable $x$ means the control rights portion, and $x_{1}^{0}=\pi, x_{1}^{0}+x_{2}^{0}=1$. Coefficient $A$ is a utility coefficient without considering the losses caused by competition of control rights. Coefficient $B$ is a limiting coefficient that reflects the cost of competition of control rights. According to the preceding concession rules designed by JØrgensen and Yeung, and assuming that government is the loser of the negotiation with a reduction of $s_{1}$, the utility function turns into Formula 12. The reductions $\mathrm{s}_{1}$ can also be calculated out.

$$
Y^{1 R}=A_{1}\left(x_{1}^{0}-s_{1}\right)-B_{1}\left(x_{1}^{0}-s_{1}\right)^{2}+A_{2}\left(x_{2}^{0}+s_{1}\right)-B_{2}\left(x_{2}^{0}+s_{1}\right)^{2}
$$

Similarly, if government is the winner, then its utility function and the reductions are respectively as follows.

$$
Y^{2 R}=A_{1}\left(x_{1}^{0}+\overline{s_{2}}\right)-B_{1}\left(x_{1}^{0}+\overline{s_{2}}\right)^{2}+A_{2}\left(x_{2}^{0}-\overline{s_{2}}\right)-B_{2}\left(x_{2}^{0}-\overline{s_{2}}\right)^{2}
$$

When the following conditions are satisfied, the purpose of this concession game is realized.

$$
\left\{\begin{array}{c}
\max \left(Y^{1 R}\right) \\
\max \left(Y^{2 R}\right) \\
Y^{1 \mathrm{R}}>Y^{0}, Y^{2 \mathrm{R}}>Y^{0} \\
Y_{1}^{1 \mathrm{R}} \geq Y_{1}^{0}, Y_{2}^{1 \mathrm{R}} \geq Y_{2}^{0} \\
Y_{1}^{2 \mathrm{R}} \geq Y_{1}^{0}, Y_{1}^{2 \mathrm{R}} \geq Y_{1}^{0}
\end{array}\right.
$$


Because of the symmetry between games, only the first case is calculated here. In order to achieve the common goal of maximizing the total utility of the project, the extreme point of function $Y$ is selected. Thus, $s_{1}$ can be calculated out.

$$
s_{1}=\frac{\left(2 B_{1}+2 B_{2}\right) \pi-\left(A_{1}-A_{2}+2 B_{2}\right)}{2 B_{1}+2 B_{2}}
$$

The changes of utility function $Y$ along with $\pi$ are shown in Fig. 4, from which we can find out that concessions can increase the total utility, but restrictions on excessive concessions make $s_{1}$ within a certain range feasible.

More specifically, excessive concessions will not be encouraged but restricted here. Moderated concessions will help to improve project value and create a governance environment of mutual trust and cooperation. In addition, by considering redistributing the added project value, the utility of government and project owner may also be enhanced.

\subsection{More Intuitive Cases}

Suppose that the government and project owner agree on seeking concession equilibrium to resolve the problem of control rights allocation. To obtain such equilibrium, this part begins with the derivations of project value with government as a loser and project owner as a winner.

Choosing the parameters as $A_{1}=12, A_{2}=10, B_{1}=4, B_{2}=5$ yields the initial, noncooperative outcome in which:

$$
\begin{gathered}
Y_{1}^{0}=12 \pi-4(\pi)^{2} \\
Y_{2}^{0}=10(1-\pi)-5(1-\pi)^{2}=5-5(\pi)^{2} \\
Y^{0}=Y_{1}^{0}+Y_{2}^{0}=5+12 \pi-9(\pi)^{2}
\end{gathered}
$$

Further, the outcome after concession game and its extreme point are obtained as:

$$
Y^{1 R}=5+12\left(\pi-s_{1}\right)-9\left(\pi-\mathrm{s}_{1}\right)^{2}=9
$$

The trends of Y with the change of $x$ are shown in Fig. 5(1). Obviously, after the concession game, the balanced project value has been improved.

And then, this research derives the payoff profile of government as a winner and project owner as a loser. Choosing the parameters as $A_{1}=8, A_{2}=10, B_{1}=3, B_{2}=2$ yields the non-

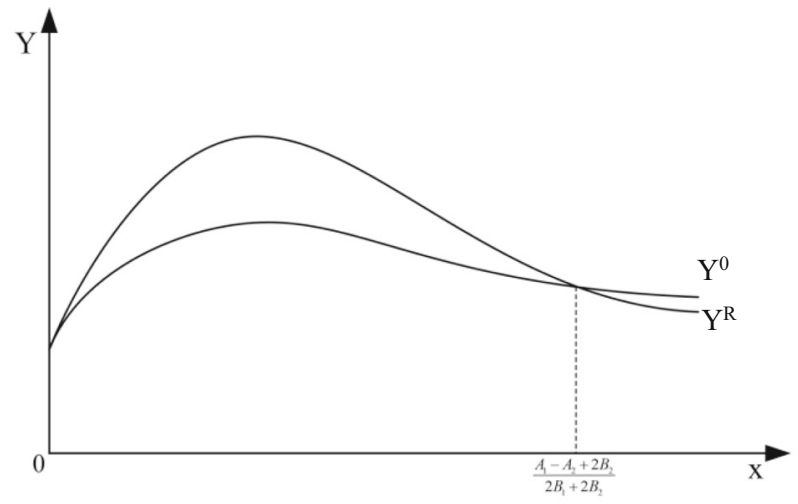

Fig. 4 Changes of utility function $Y^{0}$ and $Y^{R}$ 

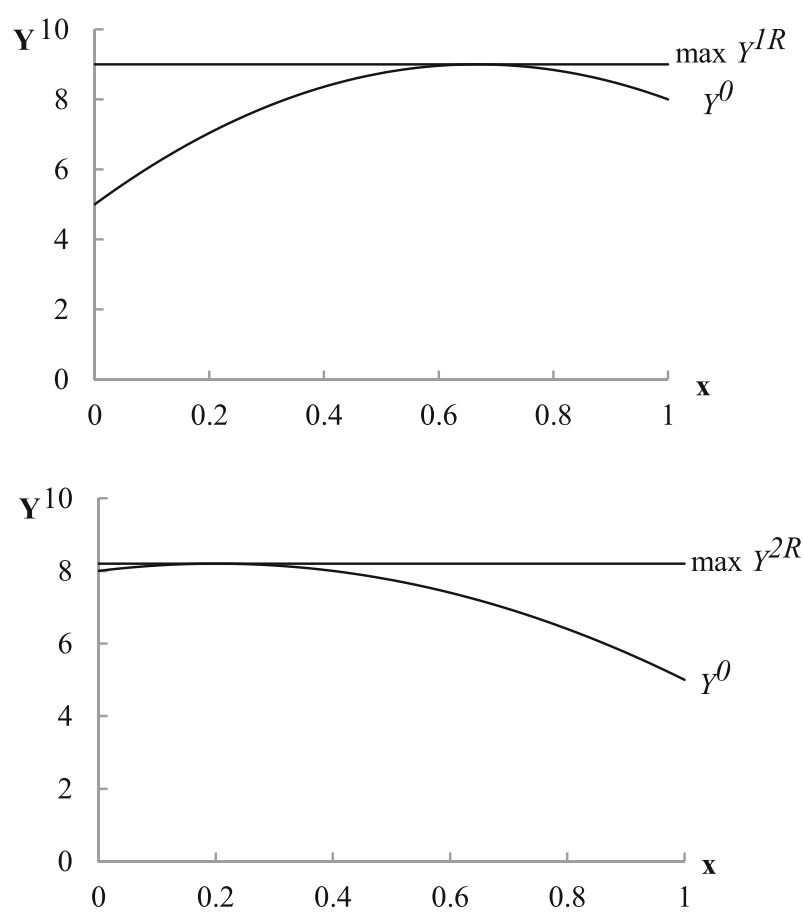

Fig. 5 (1) Outcome trends among the first game case. (2) Outcome trends among the second game case

cooperative outcome and the cooperative outcome. The trend of Y with the change of $x$ in this situation are shown in Fig. 5(2). Although the trend is different from Case 1, the balanced project value is still increased.

$$
\begin{gathered}
Y_{1}^{0}=8 \pi-3(\pi)^{2} \\
Y_{2}^{0}=10(1-\pi)-2(1-\pi)^{2}=8-6 \pi-2(\pi)^{2} \\
Y^{0}=Y_{1}^{0}+Y_{2}^{0}=8+2 \pi-5(\pi)^{2} \\
Y^{2 R}=8+2\left(\pi+\overline{s_{2}}\right)-5\left(\pi+\overline{s_{2}}\right)^{2}=8.2
\end{gathered}
$$

Moreover, the added percentages of project value in two cases are also calculated out as shown in formulas (19) and (20). Obviously, no matter who the winner is, the project value can be improved by $12.50 \%$ and $11.82 \%$ on average. It also implies that these are the gains that can be redistributed by government and project owner, and thereby increase the utility of both sides.

$$
\begin{aligned}
& R A_{1}=\frac{\operatorname{Max} Y^{1 R}-\int_{0}^{1} Y^{0} d \pi}{\int_{0}^{1} Y^{0} d \pi}=\frac{9-\int_{0}^{1}\left[5+12 \pi-9(\pi)^{2}\right] d \pi}{\int_{0}^{1}\left[5+12 \pi-9(\pi)^{2}\right] d \pi}=12.50 \% \\
& R A_{2}=\frac{\operatorname{Max} Y^{2 R}-\int_{0}^{1} Y^{0} d \pi}{\int_{0}^{1} Y^{0} d \pi}=\frac{8.2-\int_{0}^{1}\left[8+2 \pi-5(\pi)^{2}\right] d \pi}{\int_{0}^{1}\left[8+2 \pi-5(\pi)^{2}\right] d \pi}=11.82 \%
\end{aligned}
$$




\section{Results and Discussion}

This research studied an intriguing project organization: project owner in China's water megaprojects, which was closely introduced in Section 2. In a water megaproject, the project owner is both a governing subject and a governed subject, while having a crucial impact on project governance structure. This study highlights how to govern the complex relationship between government and project owner. It is established that project governance can improve project value and the quality of working relationships between the government and the project owner through a method of control rights allocation. A concession game was applied to solve the problem of control rights allocation and verify previous theoretical conjectures. The game has a cooperative spirit in the sense that moderated concessions will help to improve project effectiveness and create a governance environment of mutual trust, enhancing the utility of each individual by redistributing the added value.

A number of conclusions can be drawn from this study. Firstly, there are some theoretical inferences:

- Initially, the government and project owner are more inclined toward the principal-steward relationship. Therefore, it is possible and imperative to build a governance environment with increased trust and cooperation, to respond to the common goals of environmental responsibility, project success, and social welfare.

- Complexity is a distinguishing feature of water megaprojects. It exists in the toplevel governance structure and is further aggravated in the relationships between government and project owner. As its central goal, the methods of project governance can allow practitioners to resolve the myriad complexities of such complex and costly undertakings.

- By allocating control rights, project governance can coordinate activity and distribute resources within projects. Moreover, a trust-based allocation method arouses the collective responsibility and intrinsic motivation of stewards, which then continually improves the cooperation between government and project owner.

Conclusions can also be drawn from the model analysis:

- The concession game theory provides a cooperative spirit in the sense that a bilateral reduction in actions is preferred by both players. $\mathrm{Y}^{\mathrm{R}}$ can achieve a larger value than $\mathrm{Y}^{0}$ in a certain range $\left(0, \frac{A_{1}-A_{2}+2 B_{2}}{2 B_{1}+2 B_{2}}\right)$, that is, the concession equilibrium improves project value, and further, enhances utility of government and project owner by redistributing the added value.

- As shown in Fig. 4, with the decreasing of $\mathrm{Y}^{0}$ and $\mathrm{Y}^{\mathrm{R}}$, they cross each other in an allocation value, and then show the opposite trend. This trend means that excessive concession cannot effectively improve the project efficiency, so the unreasonable concessions for allowance will not be encouraged.

- Although concession strategy does not necessarily lead to Pareto optimality of government and project owner, it can certainly lead to Pareto upgrading by redistributing the added part of project value, thus the worth of cooperation can be reflected. 


\section{Conclusion and Limitations}

This study offers a new perspective on governing inter-organizational relationships. Furthermore, our findings offer some helpful recommendations for improving the cooperative spirit valued by stakeholders in the future megaprojects. Likewise, it validates control rights allocation as an effective governance method for enhancing project value and cooperative relationships, both important topics in the research and practice of project governance. These findings contribute to the research literature concerning control rights allocation in publicprivate partnerships and the governance of politically connected project leaders. As well, it serves as a starting point for future empirical analyses of the implications of control rights structure for megaproject success.

The particular setup involved in this study also poses certain limitations. While mightily eliminating this localism, this study is necessarily constrained in its focus on projects located in China. Such a special institutional background in China greatly determines or influences the design of project governance structure, and then affects the effect of project governance. Thus, global and extensive research in the future will be urgent and more meaningful. Besides, research addressing topics of ecological import in water megaprojects are more relevant than before given the Covid-19 situation. Achieving a balance between economic and social considerations, and to view them as serving the same societal goals, is crucial to future development policy for water megaprojects. Moreover, organizational behavior is more complex and will bring about dynamic evolution in project processes. Thus, a temporal and dynamic examination of project governance regimes may be a focus of future research.

Acknowledgments The authors appreciate the financial support from the China Scholarship Council (No. 201806710040), the National Natural Science Foundation of China (No. 71402045), and the National Social Science Foundation of China (No. 19FJYB004). We wish to thank all participants who contributed to make this possible.

\section{Compliance with Ethical Standards}

Conflict of Interest The authors declare no conflicts of interest.

\section{References}

Ahola T, Ruuska I, Artto K, Kujala J (2014) What is project governance and what are its origins? Int J Proj Manag 32(8):1321-1332. https://doi.org/10.1016/j.ijproman.2013.09.005

António FT (2017) Ten years after: revisiting the determinants of the adoption of municipal corporations for local service delivery. Local Gov Stud 43(5):697-706. https://doi.org/10.1080/03003930.2017.1356723

Badewi A (2016) The impact of project management (PM) and benefits management (BM) practices on project success: towards developing a project benefits governance framework. Int J Proj Manag 34(4):761-778. https://doi.org/10.1016/j.ijproman.2015.05.005

Besley T, Ghatak M (2001) Government versus private ownership of public goods. Q J Econ 116(4):1343-1372. https://doi.org/10.1162/003355301753265598

Brady T, Davies A (2014) Managing structural and dynamic complexity: a tale of two projects. Proj Manag J 45(4):21-38. https://doi.org/10.1002/pmj.21434

Brahm F, Tarziján J (2015) Does complexity and prior interactions affect project procurement? Evidence from mining mega-projects. Int J Proj Manag 33(8):1851-1862. https://doi.org/10.1016/j.ijproman.2015.08.005

Brunet M (2018) Governance-as-practice for major public infrastructure projects: a case of multilevel project governing. Int J Proj Manag 37:283-297. https://doi.org/10.1016/j.ijproman.2018.02.007 
Brunet M, Aubry M (2018) The governance of major public infrastructure projects: the process of translation. Int J Manag Proj Bus 11(1):80-103. https://doi.org/10.1108/IJMPB-08-2017-0095

Caniëls MC, Gelderman CJ, Vermeulen NP (2012) The interplay of governance mechanisms in complex procurement projects. J Purch Supply Manag 18(2):113-121. https://doi.org/10.1016/j.pursup.2012.04.007

Chi CS, Ruuska I, Levitt R, Ahola T, Artto K (2011) A relational governance approach for megaprojects: case studies of Beijing T3 and bird's nest projects in China. Proc., EPOC 2011 Conf., EstesPark, CO

Danwitz S (2018) Organizing inter-firm project governance - a contextual model for empirical investigation. Int J Manag Proj Bus 11(1):144-157. https://doi.org/10.1108/IJMPB-07-2017-0072

Davis JH, Schoorman FD, Donaldson L (1997) Towards a stewardship theory of management. Acad Manag Rev 22(1):20-47. https://doi.org/10.5465/amr.1997.9707180258

Defense Acquisitions (2013) Assesments of the selected weapon programs. US Government, Washington DC report (GAO)-13-294SP

Derakhshan R, Turner R, Mancini M (2019) Project governance and stakeholders: a literature review. Int J Proj Manag 37 (1):98-116

Eweje J, Turner R, Müller R (2012) Maximizing strategic value from megaprojects: the influence of informationfeed on decision making by the project manager. Int J Proj Manag 30(6):639-651. https://doi.org/10.1016/j. ijproman.2012.01.004

Fan JP, Wong TJ, Zhang T (2007) Politically connected CEOs, corporate governance and post-IPO performance of China's newly partially privatized firms. J Financ Econ 84:33-357. https://doi.org/10.1016/j. jineco.2006.03.008

Flyvbjerg B (2014) What you should know about megaprojects and why: an overview. Proj Manag J 45(2):6-19. https://doi.org/10.1002/pmj.21409

Flyvbjerg B, Turner JR (2017) Do classics exist in megaproject management? Int J Proj Manag 36(2):334-341. https://doi.org/10.1016/j.ijproman.2017.07.006

Francesconi M, Muthoo A (2006) Control rights in public-private partnerships. Social Science Electronic Publishing, 2(1), 26-27. SSRN: https://ssrn.com/abstract=924197

Frey T (2017) Megaprojects set to explode to 24\% of global GDP within a decade. Future Constr. 10 (February, https://futureofconstruction.org/blog/megaprojects-set-to-explode-to-24-of-global-gdp-within-a-decade/, retrieved May 10, 2017)

Geraldi J, Maylor H, Williams T (2011) Now, let's make it really complex (complicated): a systematic review of the complexities of projects. Int J Oper Prod Manag 31(9):966-990. https://doi.org/10.1108 $/ 01443571111165848$

Hernandez M (2012) Toward an understanding of the psychology of stewardship. Acad Manag Rev 37(2):172193. https://doi.org/10.5465/amr.2010.0363

Hoskisson RE, Gambeta E, Green CD, Li TX (2018) Is my firm-specific investment protected? Overcoming the stakeholder investment dilemma in the resource-based view. Acad Manag Rev 43(2):284-306

$\mathrm{Hu}$ Y, Chan AP, Le Y (2015) Understanding the determinants of program organization for construction megaproject success: case study of the shanghai expo construction. J Manag Eng 31(5):05014019. https://doi.org/10.1061/(ASCE)ME.1943-5479.0000310

Jessop B (2005) The governance of complexity and the complexity of governance, revisited. In: Complexity, science and society conference, 2005-09-112005-09-14. Available at http://eprints.lancs.ac.uk/218/

JØrgensen S, Yeung DWK (1999) A strategic concession game. International Game Theory Review 1(1):103129. https://doi.org/10.1142/S0219198999000086

Joslin R, Müller R (2016) The relationship between project governance and project success. Int J Proj Manag 34(4):613-626. https://doi.org/10.1016/j.ijproman.2016.01.008

Klakegg OJ, Williams T, Magnussen OM, Glasspool H (2008) Governance frameworks for public project development and estimation. Proj Manag J 39:S27-S42. https://doi.org/10.1002/pmj.20058

Ma T, Wang Z, Ding J (2018) Governing the moral hazard in china's sponge city projects: a managerial analysis of the construction in the non-public land. Sustainability 10:3018. https://doi.org/10.3390/su10093018

Mai Q, An S, Lin H, Gao XL (2018) Complexity and adaptive organization of mega project: the case of Hong Kong-Zhuhai-Macau bridge. J Manag Sci 31(3):86-99. https://doi.org/10.3969/j.issn.672-0334.2018.03.008

Martin JA, Butler FC (2017) Agent and stewardship behavior: how do they differ? J Manag Organ 23(5):633646. https://doi.org/10.1017/jmo.2016.72

Ministry of Water Resources (2015) Regulations on Project Management of water conservancy project construction. Chinese government. Available at http://www.mwr.gov.cn/zw/zcfg/bmgz/201707 /t20170714 960218.html

Müller R (2009) Project governance. Gower Publishing, Surrey. ISBN 9781315245928

Peng D, Heim G, Mallick D (2014) Collaborative product development: the effect of project complexity on the use of information technology tools and new product development practices. Prod Oper Manag 23(8):14211438. https://doi.org/10.1111/j.1937-5956.2012.01383.x 
Pfeffer J (1987) A resource dependence perspective on intercorporate relations. In: Mizruchi MS, Schwartz M (eds) Intercorporate relations: the structural analysis of business. Cambridge University Press, New York, pp 25-55. ISBN 0-521-33503-5

Pich MT, Loch CH, Meyer AD (2002) On uncertainty, ambiguity, and complexity in project management. Manag Sci 48(8):1008-1023. https://doi.org/10.1287/mnsc.48.8.1008.163

Pierce JL, Kostova T, Dirks KT (2003) The state of psychological ownership: integrating and extending a century of research. Rev Gen Psychol 7:84-107. https://doi.org/10.1037/1089-2680.7.1.84

Pinto JK (2006) Organizational governance and project success: lessons from Boston's big dig. Presentation at: concept symposium - principles of governance of major investment projects, Trondheim, Norway

Pinto JK, Slevin DP (2013) Critical factors in successful project implementation. IEEE Trans Eng Manag EM34(1):22-27. https://doi.org/10.1109/TEM.1987.6498856

Pitsis A, Clegg S, Freeder D, Sankaran S, Burdon S (2018) Megaprojects redefined - complexity vs cost and social imperatives. Int J Manag Proj Bus 11(1):7-34. https://doi.org/10.1108/IJMPB-07-2017-0080

Rolstadås A, Schiefloe P (2017) Modelling project complexity. Int J Manag Proj Bus 10(2):295-314. https://doi. org/10.1108/IJMPB-02-2016-0015

Sanderson J (2012) Risk, uncertainty and governance in megaprojects: a critical discussion of alternative explanations. Int J Proj Manag 30(4):432-443. https://doi.org/10.1016/j.ijproman.2011.11.002

Sha KX (2017) Ten lectures on construction project governance. China Architecture \& Building Press. ISBN: 9787112210435

Shenhar AJ (2001) One size does not fit all projects: exploring classical contingency domains. Manag Sci 47(3): 394 414. https://doi.org/10.1287/mnsc.47.3.394.9772

Shirley M, Walsh P (2000) Public versus private ownership: the current state of the debate. Policy Research Working Paper, 10(5), 1178-1191. https://doi.org/10.1596/1813-9450-2420

Shleifer A, Vishny RW (1989) Management entrenchment: the case of manager-specific investments. J Financ Econ 25(1): 123-139. https://doi.org/10.1016/0304-405X(89)90099-8

Solak S, Clarke JPB, Johnson EL, Barnes ER (2010) Optimization of r\&d project portfolios under endogenous uncertainty. Eur J Oper Res 207(1):420-433. https://doi.org/10.1016/j.ejor.2010.04.032

Tadelis S (2002) Complexity, flexibility, and the make-or-buy decision. Am Econ Rev 92(2):433-437. https://doi.org/10.1257/000282802320191750

Turner JR (2006) Towards a theory of project management: the nature of project governance and project management. Int J Proj Manag 24:93-95. https://doi.org/10.1016/j.ijproman.2005.11.008

Turner JR, Müller R (2003) On the nature of the project as a temporary organization. Int J Proj Manag 21(1):1-7. https://doi.org/10.1016/S0263-7863(02)00020-0

Van Marrewijk A, Smits K (2016) Cultural practices of governance in the Panama Canal expansion megaproject. Int J Proj Manag 34(3):533-544. https://doi.org/10.1016/j.ijproman.2015.07.004

Van Slyke D (2007) Agents or stewards: using theory to understand the government-nonprofit social services contracting relationship. J Public Admin Res Theory 17:157-187. https://doi.org/10.1093/jopart/mul012

Volden HG, Andersen B (2018) The hierarchy of public project governance frameworks: An empirical study of principles and practices in Norwegian ministries and agencies. Int J Manag Proj Bus 11(1):174-197. https://doi.org/10.1108/IJMPB-04-2017-0040

Wang G, He Q, Meng X, Locatelli G, Yu T, Yan X (2017) Exploring the impact of megaproject environmental responsibility on organizational citizenship behaviors for the environment: a social identity perspective. Int $\mathrm{J}$ Proj Manag 35(7):1402-1414. https://doi.org/10.1016/j.ijproman.2017.04.008

Xie LL, Xia B, Hu Y, Shan M, Le Y, Chan AP (2017) Public participation performance in public construction projects of South China: a case study of the Guangzhou games venues construction. Int J Proj Manag 35(7): 1391-1401. https://doi.org/10.1016/j.ijproman.2017.04.003

Zhi Y, Hamilton PB, Wang X, Zhang Z, Liang L (2018) Game theory analysis of the virtual water strategy. Water Resour Manag 32(14):4747-4761. https://doi.org/10.1007/s11269-018-2081-7

Publisher's Note Springer Nature remains neutral with regard to jurisdictional claims in published maps and institutional affiliations. 